\title{
Disorder-associated locus
}

INSERM

\section{Source}

INSERM. (1999). Orphanet: an online rare disease and orphan drug data base. disorderassociated locus. ORPHA:410297

Chromosomal region associated with a hereditary disorder but without any precision on the possible associated gene. 